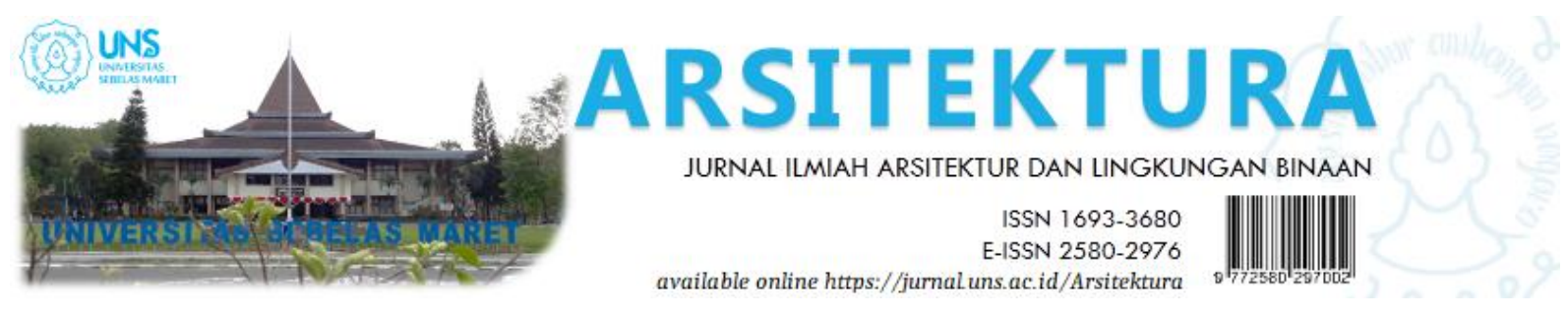

Volume 18 Issue 2 October 2020, pages:337-350

\title{
Identifikasi dan Konsep Pengembangan Kawasan Ruang Terbuka Hijau (RTH) Kota Padangsidimpuan
}

\author{
Identification and Development Green Concepts \\ Open Space Area Padangsidimpuan City
}

\author{
Yunita Syafitri Rambe ${ }^{1^{*}}$ \\ Program Studi Arsitektur, Fa kultas Teknik ${ }^{1 *}$ \\ Universita s Medan Area \\ Email: yunirambe@staff.uma.ac.id
}

DOI: https://doi.org/10.20961/arst.v18i2.44377

Received: September 15,2020 Revised: October 24, 2020 Accepted: October 25, 2020 Available online: October 31, 2020

\begin{abstract}
Urban areas in Indonesia tend to experience a typical problem, namely the high rate of population growth due to urbanization which causes the management of urban space to become incre asingly difficult. The high and increasing number of urban population has implications for the high pressure on the use of urban space, so that it is necessary to organize the space in urban areas, especially public and social facilities as well as public open spaces in urban areas. Padangsidimpuan City is one of the cities in North Sumatra Province that has green open spaces but has not received special attention. So it is necessary to do research on identification and development. This is done with the aim of creating a comfortable, productive and sustainable urban space to create a sustainable existence of publicopen spaces in urban areas. The me thod used in this research is qualitative and quantitative methods with literature, interview, survey and recording techniques which later the data obtained will be analyzed for the development of g reen open spaces (RTH). It is hoped that the results of this research will be useful as a basicfoundation for interested parties in developing and in further research.
\end{abstract}

Keywords: identification, development, green concepts open space area, Padangsidimuan

\section{PENDAHULUAN}

Lingkungan perkotaan hanya berkembang secara ekonomi, namun menurun secara ekologi. Padahal keseimbangan lingkungan perkotaan secara ekologi sama pentingnya dengan perkembangan nilai ekonomi kawasan perkotaan. Kualitas ruang terbuka publik, terutama ruang terbuka hijau (RTH) pada 30 tahun terakhir, mengalami penurunan yang sangat signifikan (Hijau \& Permukiman, 2012).

Menurunnya kuantitas dan kualitas ruang terbuka publik tersebut, baik berupa Ruang terbuka hijau (RTH) dan ruang terbuka nonhijau, telah mengakibatkan menurunnya kualitas lingkungan perkotaan seperti seringnya terjadi banjir di perkotaan, tingginya polusi udara, dan meningkatnya kerawanan sosial, serta menurunnya produktivitas masyarakat akibat stress karena terbatasnya ruang yang tersedia untuk interaksi sosial.

Ruang Terbuka Hijau Kota Padangsidimpuan hanya berkisar 5\% dari total luas lahan pemekaran dari Kabupaten Tapanuli Selatan. (Antara Sumut, 2019) Menurut Wahyu, n.d 
dimana seharusnya berdasarkan peraturan yang ada, sebuah kota harus memiliki 30 persen dari luas wilayah kota untuk dijadikan sebagai suatu Ruang Terbuka Hijau. Sesuai dengan Idealnya sebuah kota memiliki RTH minimal $30 \%$ dari total luas kota, mengacu pada KTT Bumi di Rio de Janeiro, Brazil (1992), dan dipertegas pada KTT Johannesburg, Afrika Selatan (2002) dan di perkuat oleh Badan Standarisasi Nasional. (SNI-03-1733-2004, 2004)

Bagi wilayah dengan ciri kekotaan kuat, senantiasa akan dihadapkan pada kondisi semakin menurunnya kualitas dan kuantitas RTH yang dapat dialokasikan, karena desakan pertumbuhan sarana dan prasarana kota, sebagai konsekuensi dari dinamika meningkatnya kebutuhan warga kota akan wadah kegiatan (Samsudi, 2010). Kondisi Fsiknya juga beragam mulai dari datar bergelombang hingga curam. Masih tersedianya Ruang Terbuka Hijau pada 6 Kecamatan Kota Padangsidimpuan yang sudaah tidak memenuhi rasio sebuah perkotaan. Dengan pertumbuhan penduduk yan cukup bertambah dan rasio ruang terbuka hijau yang sudah tidak memenuhi standart kelayakan perkotaan dikhawatirkan rasio semakin kecil karena ditutupi oleh bangunan. Perlu adanya strategi dan kebijakan Pemerintah dalam pengembangan Ruang Terbuka Hijau. Hal ini menjadi dasar pemikiran dilakukannya penelitian. Perlu adanya identifikasi terhadap Ruang Terbuka Hijau (RTH) yang sesuai dengan klasifikasi teori RTH dan peraturan pemerintah di Kota Padangsidimpuan terhadap 6 Kecamatannya sehingga dengan adanya identifikasi ini akan menghasilkan pra konsep perancanga RTH di Kota Padangsidimpuan. Hal ini bertujuan dapat bermanfaat bagi landasan dasar identifikasi RTH di Kota Padangsidimpuan untuk dijadikan pengembangan sebuah kota.

Menurut Permen PU No. 5/PRT/2008) bahwasannya Ruang Terbuka Hijau (RTH) merupakan bagian dari ruang-ruang terbuka (open spaces) dalam penataan ruang suatu perkotaan yang diisi oleh tumbuhan, tanaman, dan vegetasi (endemik, introduksi) guna mendukung manfaat langsung dan/atau tidak langsung yang dihasilkan oleh RTH dalam kota tersebut yaitu keamanan, kenyamanan, kesejahteraan, dan keindahan wilayah perkotaan.(Undang-Undang, 2008).
Ruang Terbuka hijau adalah area memanjang/jalur dan/atau mengelompok, yang penggunaannya lebih bersifat terbuka, tempat tumbuh tanaman, baik yang tumbuh secara alamiah (Direktorat Jenderal Penataan Ruang, 2008). Dalam Peraturan Menteri Dalam Negeri No.1 Tahun 2007 tentang Penataan Ruang Terbuka Hijau Kawasan Perkotaan, ruang terbuka hijau kawasan perkotaan adalah bagian dari ruang terbuka suatu kawasan perkotaan yang diisi oleh tumbuhan dan tanaman guna mendukung manfaat ekologi, sosial, budaya, ekonomi dan estetika. (Menteri Dalam Negeri, 2007). Dilihat dari sifatnya ruang terbuka bisa dibedakan menjadi ruang terbuka privat (memiliki batas waktu tertentu untuk mengaksesnya dan kepemilikannya bersifat pribadi, contoh halaman rumah tinggal), ruang terbuka semi privat (ruang publik yang kepemilikannya pribadi namun bisa diakses langsung oleh masyarakat, contoh Senayan, Ancol) dan ruang terbuka public (kepemilikannya oleh pemerintah dan bisa diakses langsung oleh masyarakat tanpa batas waktu tertentu, contoh alun-alun, trotoar). Selain itu ruang terbuka pun bisa diartikan sebagai ruang interaksi.

Dalam Peraturan Menteri Pekerjaan Umum nomor: 05/PRT/M/2008 tentang Pedoman Penyediaan dan Pemanfaatan Ruang Terbuka Hijau di Kawasan Perkotaan di jelaskan jenis dan sifat dari ruang terbuka hijau (RTH). Secara fisik RTH dapat dibedakan menjadi RTH alami berupa habitat liar alami, kawasan lindung dan taman-taman nasional serta RTH non alami atau binaan seperti taman, lapang an olahraga, pemakaman atau jalur-jaur hijau jalan. Dilihat dari fungsi RTH dapat berfung si ekologis, sosial budaya, estetika, dan ekonomi. Secara struktur ruang, RTH dapat mengikuti pola ekologis (mengelompok, memanjang, tersebar), maupun pola planologis yang mengikuti hirarki dan struktur ruang perkotaan. Dari segi kepemilikan, RTH dibedakan ke dalam RTH publik dan RTH privat. (Hijau \& Permukiman, 2012)

Secara kualitas, RTH perlu dibangun dan dikembangkan untuk memenuhi beberapa kebutuhan dasar penghuninya. Faktor-faktor pertimbangan itu mencakup pertimbangan (Budi Santoso, 2012): a) Fisik atau dasar eksistensi lingkungan dengan membuat bentuk-bentuk geografis sesuai 
geotopograsinya b) Sosial, untuk medorong penghuninya bersosialisasi c) Ekonomi, untuk memberi peluang pengembangkan sumber produk yang bisa dijual (misal : bahan makanan berupa : bunga, buah, dedaunan/sayur mayur, bahkan untuk dipanen umbi dan atau akarnya d) Budaya, sebagai ruang untuk mengekspresikan seni-budaya masyarakat e) Kebutuhan akan terlayaninya hak-hak manusia (penduduk) untuk mendapatkan lingkungan yang aman (termasuk dari segi pentingnya kesehatan), nyaman, indah dan lestari yaitu fungsional dan estetis. Secara umum penataan ruang ditujukan untuk menghasilkan suatu perencanaan tata ruang yang kita inginkan dimasa yang akan datang. Rencana tersebut lalu diwujudkan dalam bentuk pemanfaatan ruang yang sesuai dengan rencana yang ditetapkan. Pada dasarnya perencanaan tata ruang perkotaan dimulai dengan mengidentifikasi kawasankawasan yang secara alami harus diselamatkan (kawasan lindung) untuk menjamin kelestarian fungsi lingkungan, dan kawasan-kawasan yang secara alami rentan terhadap bencana(prone to natural hazards) seperti gempa, longsor, banjir maupun bencana alam lainnya. Ada dua manfaat Ruang Terbuka Hijau (RTH) pada kawasan perkotaan yaitu (Direktorat Jenderal Penataan Ruang, 2008) : a) Manfaat langsung (dalam pengertian cepat dan bersifat tangible), yaitu membentuk keindahan dan kenyamanan (teduh, segar, sejuk) dan mendapatkan bahanbahan untuk dijual (kayu, daun, bunga, buah). b) Manfaat tidak langsung (berjangka panjang dan bersifat intangible), yaitupembersih udara yang sangat efektif, pemeliharaan akan kelangsungan persediaan air tanah, pelestarian fungsi lingkungan beserta segala isi flora dan fauna yang ada (konservasi hayati atau keanekaragaman hayati). Berdasarkan ketentuan mengenai jenis-jenis RTHKP dijelaskan pada Permendagri No. 1 Tahun 2007 Tentang Penataan Ruang Terbuka Hijau Kawasan Perkotaan meliputi 23 jenis yaitu sebagai berikut : a) Taman Lingkungan; b) Taman Kecamatan c) RTH taman kota; d) Hutan Kota e) RTH jalur jalan hijau; f) RTH ruang pejalan kaki; g) Jalur hijau sempadan rel kereta api; h) Jalur hijau pada jaringan tegangan tinggi; i) RTH sempadan sungai; $j$ ) RTH sumber air baku/mata air; k) RTH pemakaman; 1) RTH lapangan olahraga
m)Perkebunan n) Pertanian lahan basah. (Susilowati \& -, 2013)

Identifikasi yang dilakukan menjadi sebuah hal penting yang dilakukan dalam penelitian ini. Dengan adanya penelitian ini, menjadi landasar dasar dalam penelitian lanjutan dan penelitian yang lebih dalam lagi dala sebuah penelitia terhadap Ruang Terbuka Hijau baik pada Kota Padangsidimpuan ataupun penelitian Ruang Terbuka Hijau pada Kota lainnya.

\section{METODE}

Metode penelitian yang diaplikasikan dalam penelitian ini adalah jenis "metode deskriptif" yakni cara menggambarkan kondisi lapangan untuk mengungkap secara akurat mengenai berbagai keadaan di lapangan pada saat penelitian berlangsung, salah satunya dengan identifikasi terhadap Kawasan Ruang Terbuka Hijau, diperlukan awalnya adanya pengelompokkan identifikasi berdasarkan klasifikasi dari tinjauan teori yang ada. (Suciyani, 2018)

Sumber data yang digunakan yakni data primer dan data sekunder. Sedangkan teknik pengumpulan data yang digunakan dalam penelitian ini adalah teknik Triangulasi (observasi, wawancara, dan studi dokumentasi) yaitu melakukan observasi terhadap kawasan Ruang Terbuka Hijau untuk dapat dilakukan identifikasi dan pengelompokaan RTH. Selanjutnya menggunakan metode wawancara kepada pihak-pihak terkait dan melakukan survey lokasi di Kota Padangsidimpuan. Data-data ini akan dilakukan identifikasi, pengelompokkan dan analisa sesuai dengan kriteria kawasan Ruang Terbuka Hijau secara kuantitatif. Dari hasil analisa, akan dilakukan konsep perencanaan RTH di Kota Padangsidimpuan dan pengambilan kesimpulan untuk mendapatkan perencanaan RTH yang berkelanjutan. Secara skematik dapat dilihat pada diagram di bawah ini 


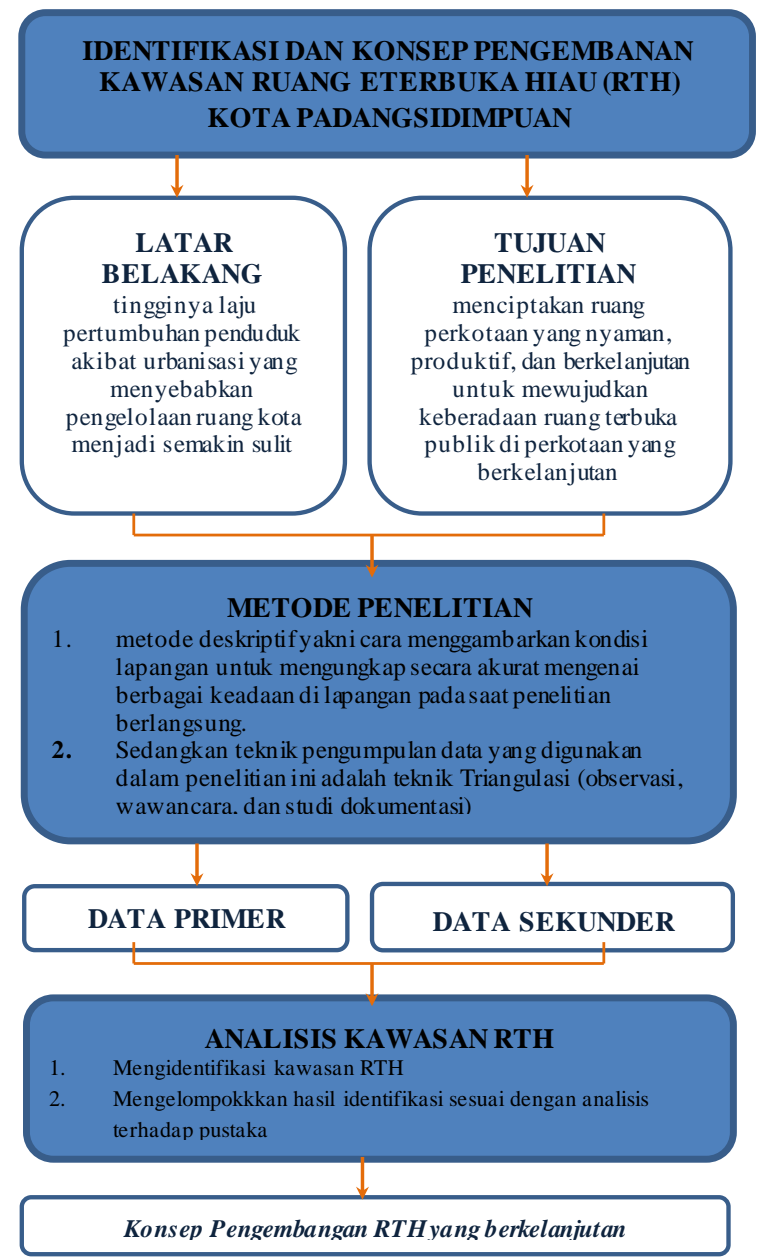

Diagram 1 Alur Penelitian

\section{HASIL DAN PEMBAHASAN}

Keberadaan Ruang Terbuka Hijau di Kota Padangsidimpuan berupa pulau jalan, lapangan olah raga, pemakaman dan Ruang Terbuka Hijau taman kota menyebar di Ibukota Kecamatan. Untuk jenis dan luas Ruang Terbuka Hijau di kota Padangsidimpuan, dapat dilihat pada table 1

Tabel 1 Jenis Dan Luas Ruang Terbuka Hijau (RTH) Di Kota Pa dangsidimpuan

\begin{tabular}{|l|l|}
\hline Jenis Tanah & Luas (Ha) \\
\hline RTH Hutan Kota & $2,692,05$ \\
\hline RTH Kawasan Sekitar Mata Air & 272,36 \\
\hline RTH Sempadan Sungai $(15 \mathrm{~m})$ & 215,81 \\
\hline RTH Sempadan Sungai $(50 \mathrm{~m})$ & $1,940,75$ \\
\hline RTH Sempadan Sungai $(100 \mathrm{~m})$ & 851,21 \\
\hline RTH Sempadan Sutet & 466,47 \\
\hline RTH Taman Kota & 0,71 \\
\hline RTH Lapangan OLahraga & 10,62 \\
\hline RTH Pemakaman & 14,84 \\
\hline RTH Pulau Jalan & 0,32 \\
\hline Luas Total & $6,464,60$ \\
\hline
\end{tabular}

Di Padangsidimpuan Hutan Kota di 6 Kecamatan dan Taman Kota terdapat di Kecamatan Padangsidimpuan Tenggara. Ruang terbuka hijau publik juga dapat berbentuk Lapangan Olah Raga, Taman Kota, dan Hutan Kota. Berikut data Lapangan Olah Raga, Taman Kota serta Hutan Kota di Kota Padangsidimpuan yang dapat dilihat pada Tabel 2 dan 3

Tabel 2 La pangan Olah Raga Di Kota Padangsidimpuan

\begin{tabular}{|l|l|l|l|}
\hline No. & Kecamatan & Jumlah & $\begin{array}{l}\text { Luas } \\
\text { (Hektar) }\end{array}$ \\
\hline 1 & PSP Hutaimbaru & 4 & 2,02 \\
\hline 2 & PSP Angkola Julu & 2 & 2,26 \\
\hline 3 & PSP Utara & 3 & 1,42 \\
\hline 4 & PSP Selatan & 3 & 1,78 \\
\hline 5 & PSP Tenggara & 3 & 2,47 \\
\hline 6 & PSP Batunadua & 1 & 0,67 \\
\hline \multicolumn{2}{|l}{ TOTAL } & 16 & 10,62 \\
\hline
\end{tabular}

Tabel 3. Hutan Kota Di Kota Padangsidimpuan

\begin{tabular}{|l|l|l|}
\hline No. & Kecamatan & Luas (Ha) \\
\hline 1 & $\begin{array}{l}\text { Padangsidimpuan } \\
\text { Angkola Julu }\end{array}$ & 306,25 \\
\hline 2 & $\begin{array}{l}\text { Padangsidimpuan } \\
\text { Hutaimbaru }\end{array}$ & 67,02 \\
\hline 3 & Padangsidimpuan Utara & 342,93 \\
\hline 4 & Padangsidimpuan Selatan & 420,15 \\
\hline 5 & $\begin{array}{l}\text { Padangsidimpuan } \\
\text { Tenggara }\end{array}$ & 581,37 \\
\hline 6 & $\begin{array}{l}\text { Padangsidimpuan } \\
\text { Batunadua }\end{array}$ & $1.248,83$ \\
\hline \multicolumn{2}{|l|}{ TOTAL LUAS } & $\mathbf{2 . 9 6 6 , 5 5}$ \\
\hline
\end{tabular}

Adapun jalur hijau dikota Padangsidimpuan terbagi menjadi beberpa jenis sebagai berikut:

1) Jalur Hijau Sepanjang Jaringan Jalan (Pulau Jalan, median jalan dan jalur pejalan kaki)

2) Jalur Hijau Di Bawah Saluran Udara Tegangan Tinggi

Kriteria kawasan sekitar jalur utama listrik tegangan tinggi diatur dalam Permen PU No. 5 Tahun 2008. Ketentuan lebar sempadan jaringan tenaga listrik yang dapat digunakan sebagai RTH adalah sebagai berikut:

1. Garis sempadan jaringan tenaga listrik adalah $64 \mathrm{~m}$ yang ditetapkan dari titik tengah jaringan tenaga listrik;

2. Ketentuan jarak bebas minimum antara pengantar SUTT dengan tanah dan benda lain 
Secara umum tidak ada patokan khusus mengenai kebutuhan ruang bagi TPU dan perkembangannya disesuaikan dengan kebutuhannya. Adapun tempat pemakaman umum di Kota Padangsidimpuan Terdiri dari :

1. Pemakaman Muslim Silandit

2. Pemakaman Pahlawan

3. Pemakaman umum di 6 Ibukota Kecamatan

4. Pemakaman Tionghoa

Adapun jumlah pemakaman Umum di Kota Padangsidimpuan dapat dilihat pada tabel 4

Tabel 4. Tempat Pemakaman Umum Di Kota Padangsidimpuan

\begin{tabular}{|l|l|l|}
\hline No & Kecamatan & $\begin{array}{l}\text { Jumlah } \\
\text { Pemakaman }\end{array}$ \\
\hline 1 & $\begin{array}{l}\text { Padangsidimpuan } \\
\text { Tenggara }\end{array}$ & 8 Lokasi \\
\hline 2 & $\begin{array}{l}\text { Padangsidimpuan } \\
\text { Selatan }\end{array}$ & 7 Lokasi \\
\hline 3 & $\begin{array}{l}\text { Padangsidimpuan } \\
\text { Batunadua }\end{array}$ & 3 Lokasi \\
\hline 4 & $\begin{array}{l}\text { Padangsidimpuan } \\
\text { Utara }\end{array}$ & 0 \\
\hline 5 & $\begin{array}{l}\text { Padangsidimpuan } \\
\text { Hutaimbaru }\end{array}$ & 2 Lokasi \\
\hline 6 & $\begin{array}{l}\text { Padangsidimpuan } \\
\text { Angkola Julu }\end{array}$ & 1 Lokasi \\
\hline Jumlah & 21 Pemakaman \\
\hline
\end{tabular}

Di Kota Padangsidimpuan, jenis-jenis ruang terbuka hijau taman sebesar di berbagai kecamatan. Jenis dan variasi ruang terbuka hijau taman dan hutan kota di Kota Padangsidimpuan ini sangat sedikit. Berikut ini merupakan ketersediaan ruang terbuka hijau (RTH) taman dan hutan kota yang terdapat di Kota Padangsidimpuan. Berdasarkan data ketersediaan ruang terbuka hijau yang ada di Kota Padangsidimpuan, jenis ruang terbuka hijau taman dan hutan kota yang ada di Kota Padangsidimpuan sangat sedikit dan beragam. Berikut beberapa ilustrasi ruang terbuka hijau berupa taman dan hutan Kota yang ada di Kota Padangsidimpuan.

Di Kota Padangsidimpuan ruang terbuka hijau dengan fungsi tertentu ini dapat berupa Ruang Terbuka Hijau jaringan listrik tegangan tinggi, pemakaman umum (TPU), buffer zone TPA dan buffer zone PLN pembangkit. Untuk Ruang Terbuka Hijau buffer zone TPA dan PLN pembangkit hanya terdapat di beberapa wilayah , sedangkan Ruang Terbuka Hijau pemakaman umum yang secara merata tersebar pada tiap-tiap wilayah kecamatan di Kota Padangsidimpuan yakni dapat dilihat pada tabel 5
Tabel 5. RTH Tempat Pemakaman Umum Di Kota Padangsidimpuan

\begin{tabular}{|c|l|l|l|l|l|}
\hline No & $\begin{array}{l}\text { Nama } \\
\text { Makam }\end{array}$ & Kecamatan & Kelurahan & Alamat & $\begin{array}{l}\text { Luas } \\
(\text { Ha })\end{array}$ \\
\hline 1 & $\begin{array}{l}\text { TPU } \\
\text { Silandit }\end{array}$ & $\begin{array}{l}\text { Padangsidimpuan } \\
\text { Selatan }\end{array}$ & $\begin{array}{l}\text { Aek } \\
\text { Tampang }\end{array}$ & $\begin{array}{l}\text { Jalan } \\
\text { Imam } \\
\text { Bonjol }\end{array}$ & 4,26 \\
\hline 2 & $\begin{array}{l}\text { Taman } \\
\text { Makam } \\
\text { Pahlawan }\end{array}$ & $\begin{array}{l}\text { Padangsidimpuan } \\
\text { Selatan }\end{array}$ & $\begin{array}{l}\text { Ujung } \\
\text { Padang }\end{array}$ & $\begin{array}{l}\text { Jalan } \\
\text { Melati }\end{array}$ & 0,73 \\
\hline
\end{tabular}

Di Kota Padangsidimpuan hutan kota berada di Kecamatan Padangsidimpuan Hutaimbaru, Kecamatan Padangsidimpuan Angkola Julu, Kecamatan Padangsidimpuan Utara, Kecamatan Padangsidimpuan Selatan, Kecamatan Padangsidimpuan Tenggara dan Kecamatan Padangsidimpuan Batunadua.

\subsection{Penyediaan RTH menurut RTRW Kota Padangsidimpuan}

Adapun rencana pengembangan Ruang Terbuka Hijau Kota yang tertuang dalam Rencana Tata Ruang Wilayah Kota Padangsidimpuan antara lain:

1) Ruang Terbuka Hijau (RTH) Publik, direncanakan hingga Tahun 2033 di Kota lebih kurang seluas $3.509,04 \mathrm{Ha}$ atau lebih kurang 22,02 persen dari luas wilayah Kota yang terdiri atas:

a. RTH taman Kota di Kecamatan Padangsidimpuan Utara, Kecamatan Padangsidimpuan Selatan, Kecamatan Padangsidimpuan Tenggara, Kecamatan Padangsidimpuan Batunadua, Kecamatan Padangsidimpuan Hutaimbaru dan Kecamatan Padangsidimpuan Angkola Julu seluas lebih kurang 8,74 Ha;

b. RTH taman wisata alam dan taman rekreasi di Kecamatan Padangsidimpuan Utara dan Kecamatan Padangsidimpuan Hutaimbaru seluas $36 \mathrm{Ha}$;

c. RTH taman lingkungan perumahan dan permukiman yang tersebar di Kecamatan Padangsidimpuan Utara, Kecamatan Padangsidimpuan Selatan, Kecamatan Padangsidimpuan Tenggara, Kecamatan Padangsidimpuan Batunadua, dan Kecamatan Padangsidimpuan Hutaimbarudan Kecamatan Padangsidimpuan Angkola Juluseluas lebih kurang12 Ha;

d. RTH taman lingkungan perkantoran, pendidikan dan gedung komersial di Desa Pal IV Pijorkoling Kecamatan 
Padangsidimpuan Tenggara, Kelurahan Batunadua Jae, Kelurahan Batunadua Julu, Desa Ujunggurap Kecamatan Padangsidimpuan Batunadua Kelurahan Sadabuan Kecamatan Padangsidimpuan Utara seluaslebih kurang111,50 Ha;

e. RTH Pekuburan dan Sentra pemakaman yang tersebar di Kecamatan Padangsidimpuan Utara, Kecamatan Padangsidimpuan Selatan, Kecamatan Padangsidimpuan Tenggara, Kecamatan Padangsidimpuan Batunadua, Kecamatan Hutaimbaru dan Kecamatan Padangsidimpuan Angkola Julu seluas lebih kurang $158 \mathrm{Ha}$;

f. RTH lapangan olahraga yang tersebar di Kecamatan Padangsidimpuan Utara, Kecamatan Padangsidimpuan Selatan, Kecamatan Padangsidimpuan Tenggara, Kecamatan Padangsidimpuan Batunadua, Kecamatan Padangsidimpuan Hutaimbaru dan Kecamatan Padangsidimpuan Angkola Julu seluas lebih kurang18 Ha;

g. RTH lahan pertanian diperkotaan yang tersebar di Kecamatan Padangsidimpuan Utara, Kecamatan Padangsidimpuan Selatan, Kecamatan Padangsidimpuan Tenggara, Kecamatan Padangsidimpuan Batunadua, Kecamatan Padangsidimpuan Hutaimbaru dan Kecamatan Padangsidimpuan Angkola Julu seluas lebih kurang1.618 Ha;

h. RTH Saluran Udara Tegangan Ekstra Tinggi (SUTET) dari Sipirok Kabupaten Tapanuli Selatan, melalui Desa Mompang - Desa Simatohir - Desa Rimba Soping - Kelurahan Batunadua Julu, dari Sibolga melalui Kelurahan Palopat Maria - Kelurahan Sabungan Jae - Kelurahan Losung Batu Kelurahan Bonan Dolok, bertemu di Kelurahan Sitamiang, terus ke arah Kabupaten Mandailing Natal melalui Kelurahan Silandit - Desa Aek Bayur Desa Pudun Jae - Desa Palopat PK Kelurahan Pijor Koling - Desa Salambue - Desa Manunggang Julu Desa Manegen, pengembangan dengan kapasitas $275 \mathrm{kV}$ dari Gunung Tua melalui Desa Bargot Topong - Desa Ujung Gurap - Desa Baruas - Desa Pudun Julu - Desa Pudun Jae - Desa
Palopat PK - Kelurahan Pijor Koling Desa Salambue - Desa Manunggang Julu - Desa Manegen, ke Provinsi Sumatera Barat, serta Pengembangan Saluran Udara Tegangan Ekstra Tinggi (SUTET) dengan kapasitas $175 \mathrm{kV}$ dari Batang Toru Kabupaten Tapanuli Selatan melalui Kelurahan Palopat Maria - Kelurahan Hutaimbaru - Desa Partihaman Saroha - Kelurahan Panyanggar - Kelurahan Hanopan Kelurahan Sidangkal - Kelurahan Sihitang, menuju Desa Palopat Pijorkoling ke Provinsi Sumatera Baratdengan luas lebih kurang108,141 $\mathrm{Ha}$;

i. RTH sempadan sungai di Kecamatan Padangsidimpuan Utara - Kecamatan Padangsidimpuan Selatan - Kecamatan Padangsidimpuan Tenggara Kecamatan Padangsidimpuan Batunadua - Kecamatan Padangsidimpuan Hutaimbaru dan Kecamatan Padangsidimpuan Angkola Julu seluas lebih kurang7,50 Ha;

j. RTH jalur pengaman jalan, median jalan, rel kerata api, pipa gas dan pedistrian di wilayah Kota Padangsidimpuan seluas lebih kurang $83,23 \mathrm{Ha}$; dan

k. RTH daerah penyangga (buffer zone) Perbukitan Sirata, Perbukitan Dolok Batu Rumbi dan Perbukitan Simulak Anjing Kelurahan Panyanggar, Desa Partihaman Saroha, Perbukitan Sihitang, Perbukitan Sopo Indah, Perbukitan Sigulang, Desa Labuhan Rasoki, Desa Labuhan Labo, Desa Perkebunan PK, Perbukitan Bukit Barisan Kecamatan Padangsidimpuan Batunadua, Kelurahan Palopat Maria, Desa TinjomanKelurahan Lembah Lubuk Manik, Kelurahan Lubuk Raya, Desa Pintu Langit Jae, Desa Simasom, Desa Simatohir,dan Desa Rimba Soping seluas lebih kurang1.347,93 Ha.

2) Ruang Terbuka Hijau (RTH) Privat direncanakan hingga Tahun 2033 di Kota lebih kurang seluas $1.636,27 \mathrm{Ha}$ atau lebih kurang 10,27persen dari luas wilayah kota yang terdiri atas:
a. RTH Permukiman Kecamatan Padangsidimpuan Utara, Kecamatan Padangsidimpuan Selatan, Kecamatan 
Padangsidimpuan Tenggara, Kecamatan Padangsidimpuan

Kecamatan Batunadua,

Hutaimbaru

Padangsidimpuan Angkola Julu seluas lebih kurang $180 \mathrm{Ha}$;

b. RTH Perdagangan dan Jasa di Kecamatan Padangsidimpuan Utara, Kecamatan Padangsidimpuan Selatan, Kecamatan Padangsidimpuan Tenggara, Kecamatan Padangsidimpuan Batunadua, Kecamatan Padangsidimpuan Hutaimbaru dan Kecamatan Padangsidimpuan Angkola Juluseluas lebih kurang $6 \mathrm{Ha}$;

c. RTH Kawasan Pariwisata Alam dan Pariwisata Buatan di Kecamatan Padangsidimpuan Utara, Kecamatan Padangsidimpuan Selatan, Kecamatan Padangsidimpuan Tenggara, Kecamatan Padangsidimpuan Batunadua, Kecamatan Padangsidimpuan Hutaimbaru dan Kecamatan Padangsidimpuan Angkola Julu seluas lebih kurang30 Ha;

d. RTH Perindustrian dan Pergudangan di Kecamatan Padangsidimpuan Utara, Kecamatan Padangsidimpuan Selatan, Kecamatan Padangsidimpuan Tenggara, Kecamatan Padangsidimpuan Batunadua, Kecamatan Padangsidimpuan Hutaimbaru dan Kecamatan Padangsidimpuan Angkola Juluseluas lebih kurang60 Ha;

e. RTH Kawasan Pertahanan dan Keamanan Kelurahan Padangmatinggi, Kelurahan Batang Ayumi Julu, Kelurahan Losung Batu seluas lebih kurang4,52 Ha; dan

f. RTH peruntukan lainnya di Kecamatan Padangsidimpuan Utara, Kecamatan Padangsidimpuan Selatan, Kecamatan Padangsidimpuan Tenggara, Kecamatan Padangsidimpuan Batunadua, Kecamatan Padangsidimpuan Hutaimbaru dan Kecamatan Padangsidimpuan Angkola Julu seluas lebih kurang 1.355,75 Ha.

\subsection{Analisa Distribusi Ruang Terbuka Hijau Taman Kota}

3.2.1 Kecamatan Padangsidimpuan Utara Di Kecamatan Padangsidimpuan Utara capaian luasan ruang terbuka hijau taman kota yaitu
0,82 Ha yang menyebar di seluruh kelurahan di kecamatan. Adapun kelurahan yang memiliki capaian luasan ruang terbuka hijau taman kota terbesar yaitu di Kelurahan Panyanggar sebesar 0,22 Ha, sedangkan kelurahan yang memiliki capaian luasan ruang terbuka hijau taman kota terkecil yaitu Kelurahan Kantin, Timbangan, Wek II, Wek III, dan Wek IV sebesar 0,01 Ha, seperti terlihat pada Tabel 6

\subsubsection{Kecamatan Padangsidimpuan Selatan}

Di Kecamatan Padangsidimpuan Selatan capaian luasan ruang terbuka hijau taman kota yaitu 1,06 Ha yang menyebar di seluruh kelurahan di kecamatan. Adapun kelurahan yang memiliki capaian luasan ruang terbuka hijau taman kota terbesar yaitu di Kelurahan Silandit sebesar 0,18 Ha, sedangkan kelurahan yang memiliki capaian luasan ruang terbuka hijau taman kota terkecil yaitu Kelurahan Sitamiang sebesar $0,02 \mathrm{Ha}$, seperti terlihat pada Tabel 7.

\subsubsection{Kecamatan Padangsidimpuan Tenggara}

Di Kecamatan Padangsidimpuan Tenggara capaian luasan ruang terbuka hijau taman kota yaitu 2,07 Ha yang menyebar di seluruh kelurahan di kecamatan. Adapun desa yang memiliki capaian luasan ruang terbuka hijau taman kota terbesar yaitu di Desa Labuhan Labo sebesar $0,37 \mathrm{Ha}$, sedangkan desa yang memiliki capaian luasan ruang terbuka hijau taman kota terkecil yaitu Desa Huta Koje Pijor Koling sebesar 0,02 Ha, seperti terlihat pada Tabel 8

\subsubsection{Kecamatan Padangsidimpuan Batunadua}

Di Kecamatan Padangsidimpuan Batunadua capaian luasan ruang terbuka hijau taman kota yaitu 2,29 Ha yang menyebar di seluruh kelurahan di kecamatan. Adapun desa yang memiliki capaian luasan ruang terbuka hijau taman kota terbesar yaitu di Desa Simirik sebesar 0,38 Ha, sedangkan desa yang memiliki capaian luasan ruang terbuka hijau taman kota terkecil yaitu Desa Aek Bayur sebesar 0,00 Ha, seperti terlihat pada Tabel 9 


\subsubsection{Kecamatan Padangsidimpuan Hutaimbaru \\ Di Kecamatan Padangsidimpuan} Hutaimbaru capaian luasan ruang terbuka hijau taman kota yaitu 1,24 Ha yang menyebar di seluruh kelurahan di kecamatan. Adapun desa/kelurahan yang memiliki capaian luasan ruang terbuka hijau taman kota terbesar yaitu di Kelurahan Lembah Lubuk Manik sebesar $0,24 \mathrm{Ha}$, sedangkan desa/kelurahan yang memiliki capaian luasan ruang terbuka hijau taman kota terkecil yaitu Desa Singali sebesar 0,05 Ha, seperti terlihat pada Tabel 10 .

\subsubsection{Kecamatan Padangsidimpuan Angkola Julu}

Di Kecamatan Padangsidimpuan Angkola Julu capaian luasan ruang terbuka hijau taman lkota yaitu 1,26 $\mathrm{Ha}$ yang menyebar di seluruh kelurahan di kecamatan. Adapun desa yang memiliki capaian luasan ruang terbuka hijau taman kota terbesar yaitu di Desa Mompang dan Desa Simatohir sebesar 0,24 Ha, sedangkan desa yang memiliki capaian luasan ruang terbuka hijau taman kota terkecil yaitu Desa Batu Layan sebesar 0,07 Ha, seperti terlihat pada Tabel 11

\subsection{Konsep Pengembangan RTH}

\subsubsection{Konsep Pengembangan Ruang Terbuka Hijau Kawasan Lindung}

Perkembangan rencana ruang terbuka hijau pada kawasan lindung adalah dengan mempertahankan kawasan lindung tersebut serta mempertahankan vegetasi yang ada sehingga kelestarian ruang terbuka hijau pada kawasan lindung tetap terjaga. Rencana perkembangan pada kawasan sempadan sungai terbagi menjadi dua yaitu untuk sungai bertanggul dan sungai tidak bertanggul. Untuk sungai bertanggul garis sempadan sungai bertanggul didalam kawasan perkotaan ditetapkan sekurang-kurangnya $3 \mathrm{~m}$ di sebelah luar sepanjang kaki tanggul. Sedangkan garis sempadan sungai tidak bertanggul di dalam kawasan perkotaan ditetapkan sekurangkurangnya $10 \mathrm{~m}$ dihitung dari tepi sungai pada waktu ditetapkan untuk sungai yang mempunyai kedalaman tidak lebih dari $3 \mathrm{~m}$, garis sempadan sekurang-kurangnya $15 \mathrm{~m}$ dihitung dari tepi sungai pada waktu ditetapkan untuk sungai yang mempunyai kedalaman lebih dari $3 \mathrm{~m}$, dan garis sempadan sekurang-kurangnya $30 \mathrm{~m}$ dihitung dari tepi sungai pada waktu ditetapkan untuk sungai yang mempunyai kedalaman $20 \mathrm{~m}$. Adapun gambaran rencana ruang terbuka hijau untuk daerah sempadan sungai seperti pada Gambar 1.

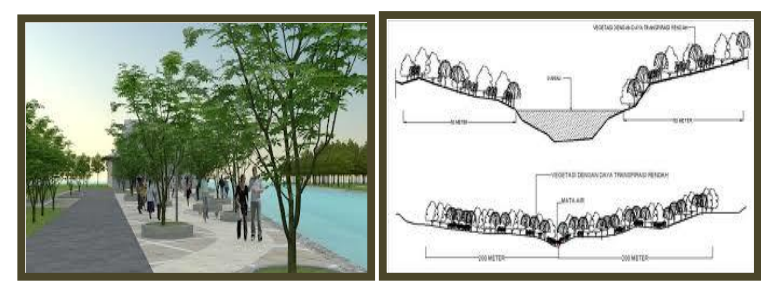

Gambar 1 Rencana Kawasan Sempadan Sungai

\subsubsection{Rencana Ruang Terbuka Hijau Taman Dan Hutan Kota}

Ruang terbuka hijau publik memiliki proporsi sekitar 20\% dari luasan kota. Untuk mencapai proporsi tersebut dapat dilakukan penghijau an berupa pembangunan ruang-ruang terbuka hijau seperti taman-taman skala lingkungan baik tingkat rukun tetangga (RT), rukun warga (RW), kelurahan, kecamatan dan taman skala kota hingga hutan kota. Perencanaan Ruang Terbuka Hijau taman dan hutan kota dapat menyebar secara merata pada tiap bagian kota. Taman kota harus mampu menciptakan ruangruang yang dinamis untuk kebutuhan berbagai penggunanya, seperti ruang untuk berkumpul bermain anak sehingga membangun dan membangkitkan pengalaman yang menyenangkan. Untuk meningkatkan kualitas peran dan fungsi taman kota sebagai ruang public, maka taman kota harus dilengkapi dengan fasilitas untuk rekreasi, interaksi, olah raga dan edukasi untuk segala usia termasuk para penyandang cacat, sehingga terwujudnya keragaman kegiatan pengunjung.(Noviana Mafazah, 2020)

a. Taman Rukun Tetangga (RT)

Luasan untuk taman $\mathrm{RT} \pm 250 \mathrm{~m}^{2}$ atau dengan standar $1 \mathrm{~m}^{2}$ per penduduk dan radius pencapaian kurang dari $300 \mathrm{~m}$. Luas area yang ditanami tanaman (ruang hijau) minimal 70\% $80 \%$ dari luas taman. Berikut rencana pola bentuk taman skala rukun tetangga (RT) yang terdiri dari dua jenis yaitu taman RT pasif dan taman RT aktif. 


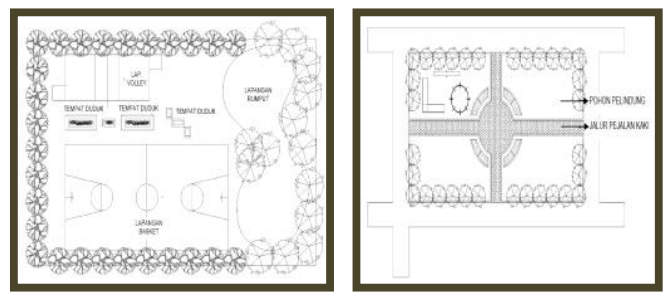

Gambar 2 Rencana Taman Rukun Tetangga (RT) Pasif

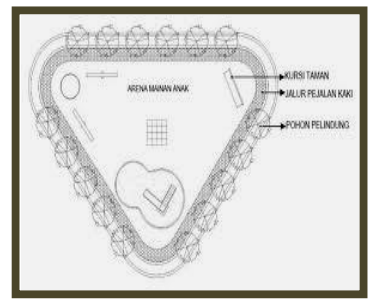

Gambar 3 Rencana Taman Rukun Tetangga (RT) Aktif

b. Taman Rukun warga (RW)

Luasan untuk taman $\mathrm{RW} \pm 1.250 \mathrm{~m}^{2}$ atau dengan standar $0,5 \mathrm{~m}^{2}$ per penduduk dan radius pencapaian $1.000 \mathrm{~m}$. Luas area yang ditanami tanaman (ruang hijau) minimal 70\%$80 \%$ dari luas taman dan sisanya dapat berupa pelataran yang diperkeras sebagai tempat melakukan berbagai aktivitas, seperti melakukan olahraga lari pagi, melakukan kumpul dan duduk-duduk untuk menikmati suasana taman. Adapun rencana gambar rencana pola taman rukun warga (RW) dapat dilihat pada ilustrasi Gambar 4 dan 5.
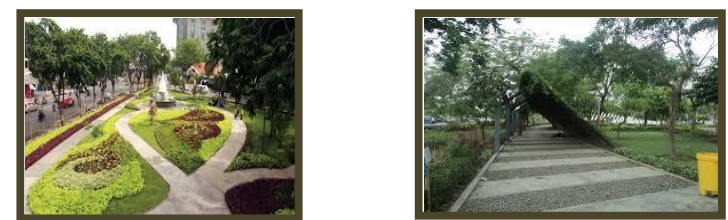

Gambar 4 Rencana Taman Warga (RW) Pa sif
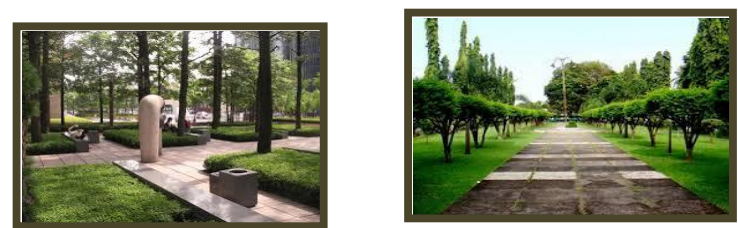

Gambar 5 Rencana Taman Warga (RW) Aktif

c. Taman Kelurahan

Luasan untuk taman kelurahan sekitar 9.000 $\mathrm{m}^{2}$ atau dengan standar $0,3 \mathrm{~m}^{2}$ per penduduk. Luas area yang ditanami tanaman (ruang hijau) minimal 80\%-90\% dari luas taman dan sisanya dapat berupa pelataran yang diperkeras sebagai tempat melakukan berbagai aktivitas seperti area jogging, area bermain anak, area duduk-duduk. Adapun rencana pola taman keluarahan dapat dilihat pada ilustrasi Gambar 6.

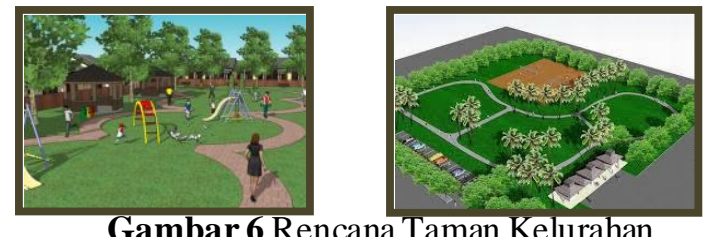

Gambar 6 Rencana Taman Kelurahan

d. Taman Kecamatan

Luasan untuk taman kecamatan sekitar 24.000 $\mathrm{m}^{2}\left(2,4\right.$ hektar) atau dengan standar $0,2 \mathrm{~m}^{2}$ per penduduk. Luas area yang ditanami tanaman (ruang hijau) minimal $80 \%-90 \%$ dari luas taman dan sisanya dapat berupa pelataran yang diperkeras sebagai tempat melakukan berbagai aktivitas, seperti area bermain, area duduk, area olahraga. Adapun pola bentuk taman skala kecamatan dapat diilustrasikan dan dilihat pada Gambar 7.
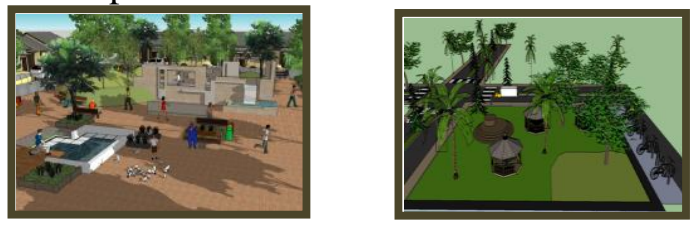

Gambar 7 Rencana Taman Kecamatan

e. Taman Kota

Luasan untuk taman kota minimal m²atau dengan standar $0,3 \mathrm{~m}^{2}$ per penduduk. Luas area yang ditanami tanaman (ruang hijau) minimal 80\%-90\% dari luas taman dan sisanya dapat berupa pelataran yang diperkeras sebagai tempat melakukan berbagai aktivitas, seperti area santai, area olahraga, area duduk. Adapun pola taman kota yang dapat diaplikasikan seperti pada Gambar 8.
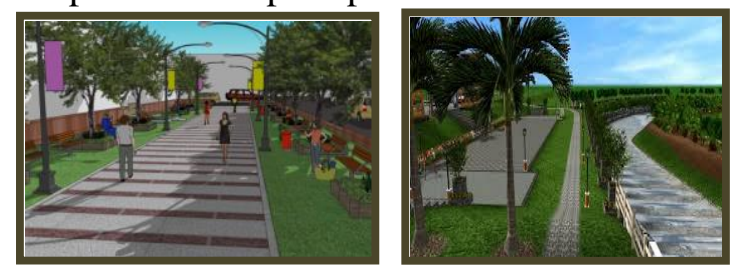

Gambar 8 Rencana Taman Kota

\section{f. Hutan Kota}

Hutan kota dapat berbentuk seperti bergerombol atau menumpuk dengan komunitas vegetasi terkonsentrasi pada satu areal, dengan jumlah vegetasi minimal 100 pohon dengan jarak tanam rapat tidak beraturan, menyebar dimana hutan kota yang tidak mempunyai pola bentuk tertentu, dengan luas minimal $2.500 \mathrm{~m}^{2}$, berbentuk jalur dimana 
hutan kota pada lahan-lahan berbentuk jalur mengikuti bentukan sungai, jalan, pantai, saluran dan lain sebagainya. Dengan lebar minimal hutan kota berbentuk jalur adalah 30 meter. Luas area yang ditanami tanaman (ruang hijau) seluas 90\%-100\% dari luas hutan kota.
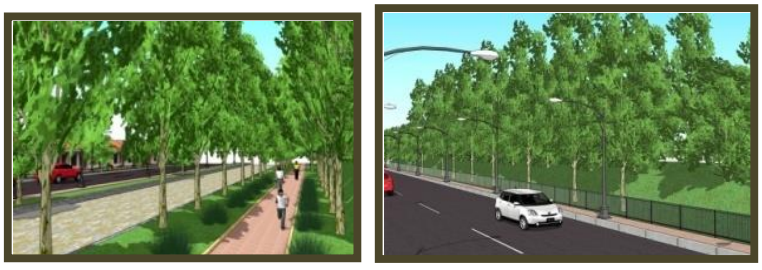

Gambar 9 Rencana Hutan Kota

\subsubsection{Rencana Ruang Terbuka Hijau Jalur Hijau Jalan}

Dalam perencanaan jalur hijau, ada beberapa hal yang harus dipertimbangkan agar tercipta jalur hijau yang selaras dan seimbang yaitu jalur penanaman, perletakan tanaman, kriteria pengaturan, bentuk dan jenis tanaman serta fungsi tanaman. Adapun perencanaan yang dilakukan dapat dilihat pada gambar 10
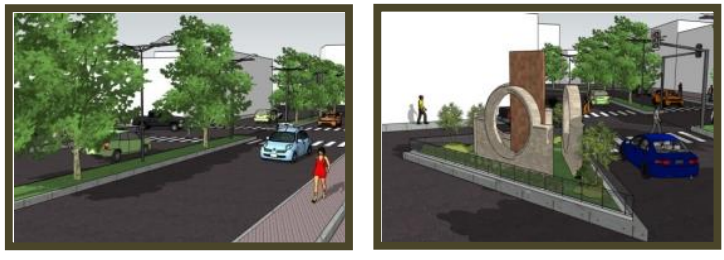

Gambar 10 encana Ruang Terbuka Hijau Ja lur Hijau Jalan

\subsubsection{Rencana Ruang Terbuka Hijau Fungsi Tertentu}

1. Ruang Terbuka Hijau Jaringan Listrik Tegangan Tinggi

Dalam menentukan ruang terbuka hijau jaringan listrik tegangan tinggi perlu memperhatikan garis sempadan jaringan tenaga listrik yakni $64 \mathrm{~m}$ yang ditetapkan dari titik tengah jaringan tenaga listrik serta memiliki kerapatan vegetasi yang cukup sekitar 50\%-60\%.

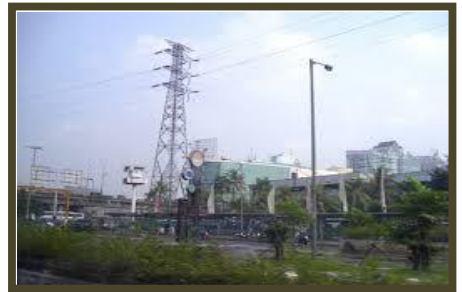

Gambar 11 Rencana Ruang Terbuka Hijau Pa da Jaringan Listrik Tega ngan Tinggi
2. Ruang Terbuka Hijau Pemakaman Umum Ruang hijau pemakaman termasuk pemakaman tanpa perkerasan minimal $70 \%$ dari total area pemakaman dengan tingkat liputan vegetasi $80 \%$ dari luas ruang hijaunya. Pemakaman dibagi dalam beberapa blok, luas dan jumlah masing-masing blok disesuaikan dengan kondisi pemakaman setempat.
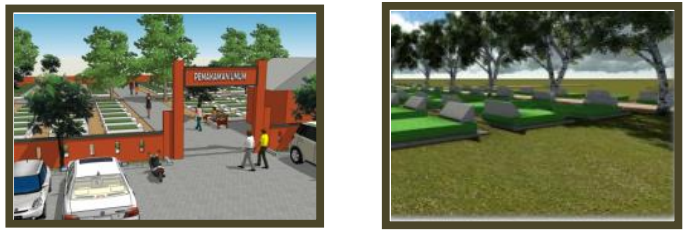

Gambar 12 Rencana Ruang Terbuka Hijau Pemakaman Umum

\section{BufferZone TPA}

BufferZone TPA berada $300 \mathrm{~m}$ dari garis terluar TPA. Lokasi tersebut cukup jauh dari area permukiman penduduk. Dalam pengembangan BufferZone ditanami pohon pelindung dengan ketebalan berkisar antara 20 $\mathrm{m}$ sampai dengan $50 \mathrm{~m}$ dari batas luar daerah operasional TPA yang didukung dengan penanaman jenis pohon yang cepat tumbuh dalam waktu 1-4 tahun.

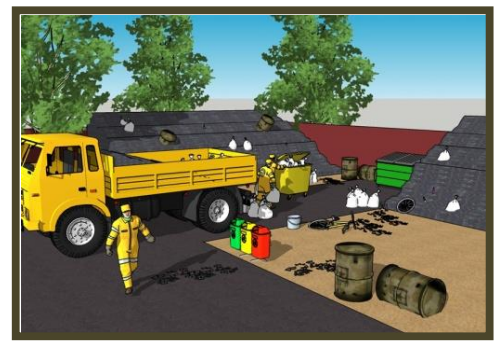

Gambar 13 Rencana Buffer Zone Tempat Pembuangan Akhir (TPA)

\section{BufferZone PLN Pembangkit}

BufferZone pada pembangkit Listrik Tenaga Diesel (PLTD) dapat dibentuk dengan arahan pengembangan berupa vegetasi yang dapat menyerap polusi udara, vegetasi yang dapat meredam kebisingan serta vegetasi yang dapat menjadi pembatas pandang.

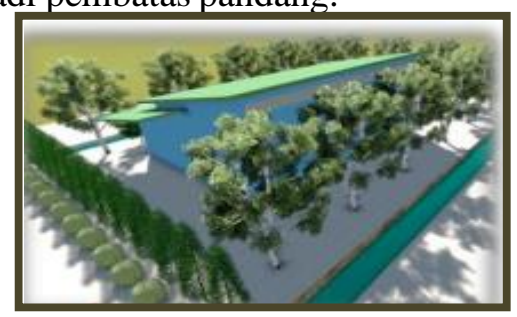

Gambar 14 Rencana Buffer Zone PLN Pembangkit 


\section{KESIMPULAN}

Kota Padangsidimpuan merupakan salah satu Kota di Provinsi Sumatera Utara yang mempunyai Ruang Terbuka Hijau, yang perlu dilakukannya konsep pengembangan sehingga tidak terkikis oleh pembangunan gedung. RTH ini menjadi penting buat sebuah kota karena merupakan paru-paru perkotaan agar terhindar dari banjir. Sehingga dengan pengembangan yang baik akan menghasilkan kota yang baik, sehat dan berkelanjutan. Dalam penelitian ini telah dilakukannya pengelompokan identifikasi terhadap RTH menjadi RTH Kawasan Lindung, RTH taman dan hutan Kota, Kawasan Hijau Jalan, Kawasan RTH dengan Fungsi lainnya seperti RTH pada Jaringan Listrik, RTK Pemakaman Umum. Bufferzone TPA BufferZone PLN Pembangkit. Hasil identifikasi dan konsep pengembangan ini dijadikan dasar bagi pengembangan kota Padangsidimpuan yang dapat digunakan bagi aparatur pemerintah dan masyarakat Kota. Sementara bagi peneliti dan pembaca dapat dijadikan acuan dasar untuk penelitian berikutnya, baik di Kota lain maupun penelitian lanjutan di Kota Padangsidimpuan.

\section{UCAPAN TERIMAKASIH}

Pada penelitian ini kami ucapkan terima kasih kepada Dinas Perumahan dan Permukiman Kota Padangsidimpuan yang telah memberikan informasi dan pendampingan dalam penelitian ini. Ucapan terimakasih juga kepada masyarakat Kota Padangsidimpuan yang telah banyak membantu dalam hal kerjasama selama penelitian.

\section{REFERENSI}

Antara Sumut. (2019). RTH Kota Padasidimpuan hanya 5 persen. Antara Sumut. https://sumut.antaranews.com/

Hijau, T., \& Permukiman, D. I. (2012). Kuantitas Dan Kualitas Ruang Terbuka Hijau Di Permukiman Perkotaan. Teknik, $30(2)$, 88-92. https://doi.org/10.14710/teknik.v30i2.186 1

Menteri Dalam Negeri. (2007). Peraturan menteri dalam negeri nomor 1 tahun 2007 tentang penataan ruang terbuka hijau kawasan perkotaan.

Noviana Mafazah, Z. H. (2020). Kajian
Implementasi Desain Universal pada Taman Samraendah. Arsitektura, 18(1), 01-12.

Samsudi. (2010). Ruang Terbuka Hijau Kebutuhan Tata Ruang Perkotaan Kota Surakarta. Journal of Rural and Development, Vol. 1(No. 1), Hal. 11-19.

SNI-03-1733-2004. (2004). Tata Cara Perencanaan Lingkungan Perumahan di Perkotaan. BSN.

Suciyani, W. O. (2018). Analisis Potensi Pemanfaatan Ruang Terbuka Hijau (Rth) Kampus Di Politeknik Negeri Bandung. Jurnal Planologi, 15(1), 17. https://doi.org/10.30659/jpsa.v15i1.2742

Susilowati, I., \& -, N. (2013). Konsep Pengembangan Ruang Terbuka Hijau (RTH) pada Permukiman Kepadatan Tinggi. Jurnal Pembangunan Wilayah \& Kota, $\quad 9(4), \quad 429$. https://doi.org/10.14710/pwk.v9i4.6680

Undang-Undang. (2008). Peraturan menteri pekerjaan umum nomor: 05/prt/m/2008 tentang pedoman penyediaan dan pemanfaatan ruang terbuka hijau di kawasan perkotaan. 
Tabel 6. Capaian Luasan Ruang Terbuka Hijau Taman Kota (Ha) Di Keca matan Padangsidimpuan Utara

\begin{tabular}{|c|c|c|c|c|}
\hline No. & Kecamatan & Desa/Kelurahan & $\begin{array}{l}\text { Luas } \\
\text { Wilayah } \\
\text { (Ha) }\end{array}$ & $\begin{array}{l}\text { Capaian Luasan Ruang } \\
\text { Terbuka Hijau Taman Kota } \\
\text { (Ha) }\end{array}$ \\
\hline \multirow{17}{*}{1.} & \multirow{17}{*}{$\begin{array}{l}\text { Padangsidimpuan } \\
\text { Utara }\end{array}$} & Kel. Batang Ayumi Jae & 27.79 & 0.02 \\
\hline & & Kel. Batang Ayumi Julu & 269.65 & 0.15 \\
\hline & & Kel. Bincar**) & 31.42 & 0.02 \\
\hline & & Kel. Bonan Dolok & 80.51 & 0.04 \\
\hline & & Kel. Kantin**) & 15.24 & 0.01 \\
\hline & & Kel. Ka yu Ombun**) & 56.80 & 0.03 \\
\hline & & Kel. Losung Batu & 321.57 & 0.18 \\
\hline & & Kel. Panyanggar & 407.76 & 0.22 \\
\hline & & Kel. Sadabuan & 68.51 & 0.04 \\
\hline & & Kel. Tano Bato & 49.42 & 0.03 \\
\hline & & Kel. Timbangan**) & 15.16 & 0.01 \\
\hline & & Kel. Tobat & 27.53 & 0.02 \\
\hline & & Kel. Wek I & 75.98 & 0.04 \\
\hline & & Kel. Wek II & 23.96 & 0.01 \\
\hline & & Kel. Wek III & 11.80 & 0.01 \\
\hline & & Kel. Wek IV & 14.80 & 0.01 \\
\hline & & JUMLAH & $1,497.90$ & 0.82 \\
\hline
\end{tabular}

Sumber: Hasil Pengolahan Data, 2020

Tabel 7. Capaian Luasan Ruang Terbuka Hijau Taman Kota (Ha) Di Kecamatan Pa dan gsidimpuan Selatan Sumber: Hasil Pengolahan Data

\begin{tabular}{|c|c|c|c|c|}
\hline No. & Kecamatan & Desa/Kelurahan & $\begin{array}{l}\text { Luas } \\
\text { Wilayah } \\
\text { (Ha) }\end{array}$ & $\begin{array}{l}\text { Capaian Luasan Ruang } \\
\text { Terbuka Hijau Taman } \\
\text { Kota (Ha) }\end{array}$ \\
\hline \multirow{13}{*}{1} & \multirow{13}{*}{ Pa dangsidim puan Selatan } & Kel. Aek Tampang & 290.54 & 0.16 \\
\hline & & Kel. Hanopan & 269.14 & 0.15 \\
\hline & & Kel. Losung & 156.38 & 0.09 \\
\hline & & Kel. Padang Matinggi & 87.79 & 0.05 \\
\hline & & Kel. Padang Matinggi Lestari**) & 63.8 & 0.04 \\
\hline & & Kel. Sidangkal & 262.22 & 0.14 \\
\hline & & Kel. Silandit & 331.48 & 0.18 \\
\hline & & Kel. Sitamiang & 42.69 & 0.02 \\
\hline & & Kel. Sitamiang baru**) & 149.27 & 0.08 \\
\hline & & Kel. Ujung Pa dang & 95.2 & 0.05 \\
\hline & & Kel. Wek V & 53.18 & 0.03 \\
\hline & & Kel. Wek VI & 125.05 & 0.07 \\
\hline & & JUMLAH & 1926.74 & 1.06 \\
\hline
\end{tabular}

Sumber: Hasil Pengolahan Data, 2020 
Tabel 8 : Capaian Luasan Ruang TerbukaHijau Taman Kota (Ha) Di Keca mata Padangsidimpuan Tenggara

\begin{tabular}{|c|c|c|c|c|}
\hline No. & Kecamatan & Desa/Kelurahan & $\begin{array}{c}\text { Luas Wilayah } \\
\text { (Ha) }\end{array}$ & $\begin{array}{c}\text { Capaian Luasan Ruang Terbuka } \\
\text { Hijau Taman Kota (Ha) }\end{array}$ \\
\hline \multirow{19}{*}{1} & \multirow{19}{*}{$\begin{array}{l}\text { Padangsidimpuan } \\
\text { Tenggara }\end{array}$} & Desa Goti & 334.56 & 0.18 \\
\hline & & Desa Huta Koje Pijor Koling & 37.24 & 0.02 \\
\hline & & Desa Huta Limbong & 46.94 & 0.03 \\
\hline & & Desa Huta Lombang & 56.49 & 0.03 \\
\hline & & Desa Huta Padang Pk & 104.92 & 0.06 \\
\hline & & Desa Labuhan Labo & 675.58 & 0.37 \\
\hline & & Desa Labuhan Rasoki & 316.88 & 0.17 \\
\hline & & Desa Manegen & 92.59 & 0.05 \\
\hline & & Desa Manunggang Jae & 103.09 & 0.06 \\
\hline & & Desa Manunggang Julu & 216.3 & 0.12 \\
\hline & & Desa Pal IV P Koling & 491.6 & 0.27 \\
\hline & & Desa Perk P Koling & 458.89 & 0.25 \\
\hline & & Kel. Pijor Koling & 152.03 & 0.08 \\
\hline & & Desa Purbatua P Koling & 96.85 & 0.05 \\
\hline & & Desa Salambue & 88.18 & 0.05 \\
\hline & & Desa Sigulang & 72.94 & 0.04 \\
\hline & & Kel. Sihitang & 343.36 & 0.19 \\
\hline & & Desa Tarutung Baru & 81.6 & 0.04 \\
\hline & & JUMLAH & 3770.04 & 2.07 \\
\hline
\end{tabular}

Sumber: Hasil Pengolahan Data, 2020

Tabel 9.Capaian Luasan Ruang Terbuka Hijau Taman Kota (Ha) Di Kecamatan Pa dangsidimpuan Batunadua

\begin{tabular}{|c|c|c|c|c|}
\hline No. & Kecamatan & Desa/Kelurahan & $\begin{array}{l}\text { Luas } \\
\text { Wilayah } \\
\text { (Ha) }\end{array}$ & $\begin{array}{lcc}\text { Capaian Luasan } & \text { Ruang } \\
\text { Terbuka Hijau } & \text { Taman } \\
\text { Kota (Ha) } & \end{array}$ \\
\hline \multirow{16}{*}{1} & \multirow{16}{*}{ Padangsidimpuan Batunadua } & Desa Aek Bayur & 7.89 & 0.00 \\
\hline & & Desa Aek Najaji & 99.24 & 0.05 \\
\hline & & Desa Aek Tuhul & 129.19 & 0.07 \\
\hline & & Desa Bargot Topong & 769.65 & 0.42 \\
\hline & & Desa Baruas & 264.86 & 0.15 \\
\hline & & Desa Batang Bahal & 383.94 & 0.21 \\
\hline & & Kel. Batunadua Jae & 406.54 & 0.22 \\
\hline & & Kel. Batunadua Julu & 244.9 & 0.13 \\
\hline & & Desa Gunung Hasahatan & 79.07 & 0.04 \\
\hline & & Desa Pudun Jae & 318.18 & 0.17 \\
\hline & & Desa Pudun Julu & 78.04 & 0.04 \\
\hline & & Desa Purwodadi & 135.67 & 0.07 \\
\hline & & Desa Siloting & 227.52 & 0.12 \\
\hline & & Desa Simirik & 692.62 & 0.38 \\
\hline & & Desa Ujung Gurap & 344.32 & 0.19 \\
\hline & & JUMLAH & 4181.63 & 2.29 \\
\hline
\end{tabular}

Sumber: Hasil Pengolahan Data, 2020 
Tabel 10. Capaian Luasan Ruang Terbuka Hijau Taman Kota (Ha) Di Kecamatan Pa dangsidimpuan Hutaimbaru

\begin{tabular}{|c|c|c|c|c|}
\hline No. & Kecamatan & Desa/Kelurahan & $\begin{array}{l}\text { Luas } \\
\text { Wilayah } \\
(\mathrm{Ha})\end{array}$ & $\begin{array}{l}\text { Capaian Luasan Ruang } \\
\text { Terbuka Hijau Taman } \\
\text { Kota (Ha) }\end{array}$ \\
\hline \multirow{11}{*}{1} & \multirow{11}{*}{$\begin{array}{l}\text { Padangsidimpuan } \\
\text { Hutaimbaru }\end{array}$} & Desa Huta Padang & 268.67 & 0.15 \\
\hline & & Kel. Hutaimbaru & 317.49 & 0.17 \\
\hline & & Kel. Lembah Lubuk Manik & 431.29 & 0.24 \\
\hline & & Kel. Lubuk Raya & 338.95 & 0.19 \\
\hline & & Kel. Palopat Maria & 162.99 & 0.09 \\
\hline & & Desa Partihaman Saroha & 107.19 & 0.06 \\
\hline & & Kel. Sabungan Jae & 106.51 & 0.06 \\
\hline & & Desa Sabungan Sipabangun & 237.87 & 0.13 \\
\hline & & Desa Singali & 98.11 & 0.05 \\
\hline & & Desa Tinjoman & 194.97 & 0.11 \\
\hline & & JUMLAH & 2264.04 & 1.24 \\
\hline
\end{tabular}

Sumber: Hasil Pengolahan Data, 2020

Tabel 11. Capaian Luasan Ruang Terbuka Hijau Taman Kota (Ha) Di Kecamatan Pa dangsidimpuan Angkola Julu

\begin{tabular}{|l|l|l|l|l|}
\hline \multirow{3}{*}{ No. } & \multirow{2}{*}{ Kecamatan } & Desa/Kelurahan & $\begin{array}{l}\text { Luas } \\
\text { Wilayah } \\
\text { (Ha) }\end{array}$ & $\begin{array}{l}\text { Capaian Luasan Ruang } \\
\text { Terbuka Hijau Taman Kota } \\
\text { (Ha) }\end{array}$ \\
\hline \multirow{5}{*}{1} & \multirow{5}{*}{ Padangsidimpuan Angkola Julu } & Desa Batu Layan & 131.35 & 0.07 \\
\cline { 3 - 5 } & & Desa Joring Lombang & 230.42 & 0.13 \\
\cline { 3 - 5 } & & Desa Joring Natobang & 246.99 & 0.14 \\
\cline { 3 - 5 } & & Desa Mompang & 442.35 & 0.24 \\
\cline { 3 - 5 } & Desa Pintu Langit Jae & 156.91 & 0.09 \\
\cline { 3 - 5 } & Desa Rimba Soping & 425.09 & 0.23 \\
\cline { 3 - 5 } & Desa Simasom & 223.21 & 0.12 \\
\cline { 3 - 5 } & Desa Simatohir & 434.18 & 0.24 \\
\cline { 3 - 5 } & & JUMLAH & 2290.5 & 1.26 \\
\hline
\end{tabular}

Sumber: Hasil Pengolahan Data, 2020 